\title{
Developing Character Education-Based Drama Textbook to increase the Ability to Play Drama
}

\author{
Retno Winarni, Karsono, Muh. Ismail S \\ Faculty of Teacher and Education, Sebelas Maret University, Surakarta, Indonesia
}

\begin{abstract}
This research was aimed to develop a textbook of drama playing technique based on character education. Research and Development method developed by Borg and Gall was used in the study. It was conducted through 4 steps, namely: (1) preliminary stage, (2) model development stage, (3) model testing stage, and (4) dissemination stage. The research approach used in the exploration stage was qualitative descriptive approach. Data collection was done through documentation study, observation, interview, and questionnaire. Data analysis technique was done using interactive analysis model. Model testing was done by conducting experimental research. The results of this research were: (1) exploration stage showed that drama textbooks used in UNS Surakarta, UMS Sukoharjo, and UNISRI Surakarta were not in accordance to the students and lecturers' need, (2) model development stage produced textbook of Drama Playing Technique based on character education through preliminary field testing; And (3) the effectiveness testing stage of the textbook (main field testing) showed the tobtained value was 8.85 which was then consulted with the value of t table (with $N=90, \alpha=$ 0.05) of 1.67. Thus, t-obtained (8.85) > t-table (1.67), the hypothesis was accepted (Ho was rejected) and the research was significant. This means the textbook of Drama Playing Techniques based on character education was effective.
\end{abstract}

Keywords - character education, contextual learning, drama playing technique, research and development, textbook

\section{INTRODUCTION}

The ability to play the drama can work well if supported by the understanding and mastery of drama playing techniques. Drama as a work of art has the value of form, value of sensory, value of knowledge, and value of life. It's just that, in an effort to achieve the aesthetics of the art figure, we should not sacrifice the moral aspect. On the one hand, the moral aspect must exist in every drama work. On the other hand, the moral aspect in the drama must be conveyed to the appreciator (children, students, viewers, audience). With drama, 'society' can be educated, directed, and influenced. Moral and art must be shoulder to shoulder in the effort to form the character and morality of the next generation (Sumaryadi, 1987).

Playing a drama is an activity that plays the characters in the script through the main tools of conversation (dialog), movement, and behavior that is staged. Waluyo (2003) reveals that many of the benefits that can be drawn from playing dramas include helping learners in understanding and using language (for communicating), practicing reading skills (drama text), practicing listening skills (drama performances dialogue, Listening to radio dramas, television and so on), practicing writing skills (simple drama text, drama reviews, staging reviews), and training speech (performing staging).

Zuriah (2007) suggests that character education aims to develop the character of students. According to Cahyoto (wy), the purpose of character education can be restored to the expectations of the community towards the school that requires students to have the thinking skills, to be a community member who has a good loyalty and possess a commendable ability. Daulay (2004) explains that the purpose of character education is to develop the values, attitudes, and behavior of students who radiate noble character. The purpose of character education makes the student a virtuous man, both in interacting with God and fellow human beings and the natural environment.

The modern education paradigm has changed some of the principles of learning. Initially the direction of learning that suppressed on the repetitive drills to develop habit has evolved and transformed into constructivist learning, ie learning that emphasizes the importance of cognitive roles to construct information (Roesmiati, 2005). The orientation of learning that is teacher oriented is now abandoned by changing it to student oriented learning, one of them is by applying new paradigm that is contextual learning.

Based on the results of the exploration stage, students and lecturers needed textbooks of drama playing techniques. So far, the drama playing technique materials were still included in Indonesian language textbook. Drama playing technique book is expected to support the success of students in learning playing drama. The ability to play dramas can increase if textbooks are available. A good textbook must meet the 
following standards: (1) in accordance with the basic competence and standards competence established by BSNP; (2) covers the time span up to about 2005; (3) includes the authors of the capital, metropolis, and regional authors; (4) in accordance with the principles of multiculturalism; (5) easy to understand; And (6) this compiled book uses a contextual approach (Djanali, 2007).

Textbooks contains specific materials used as learning and teaching guidelines at school (Richards \& Rodgers, 2002). Textbooks are usually used in conjunction with other learning resources such as workbooks, teacher reference books or supporting texts (Tomlinson \& Masuhara, 2008). In needs of the textbook, this research is urgent and needs to be done in bachelor degree of Primary Teacher Education Study Program in Surakarta area.

\section{METHOD}

The type of research used in this study is a development study developed by Borg and Gall (2003). Furthermore, Borg and Gall said that research and development is a process used to develop and validate educational products. Seals and Richey (1994) suggested that development research is a systematic review of the design, development and evaluation of programs, processes and products of learning which must meet the criteria of validity, practicality and effectiveness. Plomp (1999) adds a "can indicate additional value" criterion.

According to Borg and Gall (2003), the research and development steps consist of 10 steps, namely: (1) preliminary study, (2) research planning, (3) design development, (4) preliminary field test, 5) revision of primary field test results, (6) main field test, (7) revision of main field test result, (8) feasibility test, (9) final revision of feasibility test result, (10) dissemination and implementation of final product. The ten steps are divided into 4 main phases, each of which includes several operational steps. The four steps are; (1) the introduction stage, (2) the model development stage, (3) the model testing stage, and (4) the dissemination and implementation stage of the model (Sukmadinata, 2010; Nurkamto, 2012).

In the exploration stage, there was in-depth study on the implementation of learning drama play on Primary Teacher Education Study Program in Surakarta area. The purpose of this activity was to analyze the needs of students and lecturers on textbooks of drama playing techniques which was considered capable in improving the students' ability to play drama optimally. The research approach used was qualitative descriptive approach. Researchers emphasized the observation of the interaction between students and lecturers in the implementation of learning drama play in the research location. Researchers also conducted interviews and questionnaires to students and lecturers, analyzing documents related to research problems.

The data of this study were obtained from various data sources available at the study sites. Types of data sources used are: 5 students and 5 lecturers, events of drama play learning activities in the classroom, and documents or archives. Data collection techniques used were documentation, observation, interviews, and questionnaires. Data analysis of this research was conducted with interactive analysis model (Miles and Huberman 1992; Sutopo, 2002), which was carried out in 2 stages: during data collection and after data collection.

In model development stage, the main objective was to produce a drama playing technique textbook model of based on character education. The prototype development of textbook models was done in the form of cycles, which is a blend of research and practice (Gall et al, 2003). The steps taken included: preparation of prototype, implementation, evaluation of implementation, and revision in a sustainable manner. The procedure used was the Glanz model theory guide (in Gall et al., 2003), which includes: data collection, analysis, data interpretation, reflection, and modification. Followed by the next cycle with the same procedure. In addition, the Zuber-Skeritt model (in Cohen 2000) showed steps includes: careful planning, implementing planning, observation, assessment, evaluation, critical analysis of implementation results, and the determination of the next cycle.

The form of development was done by testing the textbook model in the field through limited trials and extensive trials. A limited trial was conducted on the Bachelor degree of Primary Teacher Education Program in UNS Surakarta. Extensive trials conducted on the Bachelor Degree of Primary Teacher Education Program in UNS Surakarta and UNISRI Surakarta.

Data collection techniques used are document analysis, participant observation, in-depth interviews, tests and focus group discussions. Data analysis was done in two ways, qualitative and quantitative. Model that has been tested then consulted with the expert with in order that developed textbook model has substantive truth and the quality can be validated.

Model Testing Stage was aimed to test the effectiveness of the textbook model of drama playing techniques based on character education in improving students' drama playing ability. Model testing is done by conducting experimental research. The type of experimental research used is quasi experimental research. The experimental research design chosen was Quasy-experimental Design Model with Non-equivalent Before-after Design 
(Wiersma, 1986; Cohen et al. 2000; Sugiyono 2012). The experimental procedures used are the concepts of Gall, Gall, \& Borg (2007) and Cohen (2000).

The experimental class used was 90 students of undergraduate program of Primary Teacher Education in UNS Surakarta. The control class was 85 students of Undergraduate program of Primary Teacher Education in UMS Surakarta. The design of this study was looking for the main effect of the textbook variable of drama playing technique based on character education toward the students' ability to play drama.

Data collection techniques used were tests of the ability to play drama. The analysis of research data was done through two stages, namely the requirements analysis test stage (normality test, homogeneity test, and equilibrium test) and the data analysis stage to test the effectiveness of the model, that is, by the mean difference test (independent test). The output of the phase was a drama playing technique textbook based on character textbook which has been tested the product and process.

In Dissemination Stage stage, the drama playing technique textbook based on character education that has been developed was published. The hope is that the textbook can be implemented on drama playing technique learning especially on Universities which have Undergraduate Program of Primary Teacher Education. Dissemination was done through national seminars and through the writing of articles in international journals as well as the publication of Textbooks of Drama Playing Techniques based on character education.

\section{RESULT AND DISCUSSION}

Procedure of development is activity steps which will be done in arranging product, that is textbook (Djanali, 2007: 16) covering: (a) planning; (b) exploration studies; (c) developing prototypes and testing effectiveness, and (d) products. Validation or prototype testing to be developed into a book through 3 phases, namely: (1) expert's judgment and revision; (2) initial trial trials for 40 students and led by two lecturers; (3) test of the effectiveness of main field testing: experimental testing conducted on 90 experimental students and 85 control students. After completing the test and repair, then the prototype can be accepted to be a textbook. Experimental tests using experimental class (PGSD UNS 90 students) and control class (PGSD UMS 85 students).

Prior to data analysis to compare textbook effectiveness, research data needs to be tested statistical requirements, including: normality test with Lilliefors technique and homogeneity test of variance with Bartlette technique. The research data that are subjected to both the requirements test (normality and homogeneity of variance) is the data or the increase value from the pretest to the postest, both from the experimental class and the the control class. Result of normality test with Lilliefors technique for experimental group obtained Lo $=0,0776$ which less than $\mathrm{Lt}=0,0930$ at real level of 0,05 with $\mathrm{N}=$ 90 , so it was concluded that research data was normal, whereas, result of normality test for control group, obtained Lo $=0.0753$ which is also smaller than $\mathrm{Lt}=$ 0,0930 , so the research data in the control group was said to be normal.

Meanwhile, the result of testing of statistical requirements with respect to homogeneity test of variance with Bartlette technique, obtained $\chi_{t}^{2}$ of 0.29 which was much larger than $\chi_{\mathrm{o}}^{2}$ of 3.84 with $\mathrm{dk}=1$ and the real level of 0.05 , so it can be expressed the variance of both values in the experimental group and the control group was homogeneous.

Hypothesis testing performed to prove the effectiveness of textbooks produced compared with the existing textbooks using t-Test techniques. The value of t-obtained (8.85) and then consulted with the value of t-table (with $\mathrm{N}$ $=90, \alpha=0.05)$ of 1.67. So, t-obtained (8.85)> t-table (1.67), then the hypothesis was accepted (Ho is rejected). Thus, it can be concluded that the textbook of Drama Playing Technique was very effective in teaching education of Drama so that it can be used as teaching material book.

\section{CONCLUSION}

Based on the research results, it could be concluded as follows. First, the research in the exploration stage showed that students and lecturers need textbook of Drama Playing Technique based on character education. Second, the prototype of Drama Playing Technique textbook includes the notion of drama, drama elements, drama-playing techniques, and drama-playing steps. The model prototype was further piloted in limited trials and extensive trials. Third, model testing was done through experimental research. Based on data analysis with independent t-test it was concluded that textbook of Drama Playing Technics based on character education was more effective compared to old textbook in improving ability to play drama for students of undergraduate program of Primary Teacher Education in Surakarta. Fourth, at the dissemination stage was done through socializing textbooks of Drama Playing Techniques based on character education in national seminars, international journals, and the publication. The results show that the textbook of Drama Playing Techniques based on character education can be accepted by lecturers, policy makers, and students. 


\section{ACKNOWLEDGEMENTS}

This research was supported by PNPB Sebelas Maret University year 2017. We thank our colleagues from Sebelas Maret University who provided insight and expertise that greatly assisted the research, although they may not agree with all of the interpretations/conclusions of this paper.

\section{REFERENCES}

[1] Borg, Walter R. dan Gall, Meredith Damien. 2003. Educational research: An Introduction. New York: Longman.

[2] Cohen, Louis et al. 2000. Research Method in Education. Great Briatin: TJ International Ltd, Padstow, Cornwall.

[3] Daulay, Haidar Putra. 2004. Pendididkan Islam dalam Sistem Pendidikan Nasional di Indonesia. Jakarta: Prenada Media.

[4] Djanali, S. D. 2007. Pengembangan Inovasi Pendidikan. Jakarta: Ditjen Dikti Depdiknas.

[5] Gall, Meredith D., Gall, Joice P.; W.R. Borg. 2007. Educational Research. Boston: Pearson Education. Inc.

[6] Miles, Matthew B. dan Huberman, A. Michael. 1992. Analisis Data Kualitatif. (terj. Tjetjeo Rohendi Rohidi)). Jakarta: universitas Indonesia.

[7] Nurkamto, Joko. 1012. "Struktur Penelitian dan Penulisan R \& D Bidang Pendidikan (Versi Borg dan Gall)". Makalah Kuliah Umum Program Pascasarjana IKIP PGRI Madiun : 30 September 2012.

[8] Plomp, Tj. 1994. 'Educational Design: Introduction", dalam Tjeerd Plomp (ed). Educational \& Training Systen Desing: Introduction Desing of Education and Training. Utrecht: Lemma. Nederlands. Faculty of Educational Science and Technology, University of Twente.

[9] Richard, JC \& Rodgers T. 2002. Approaches and Methods in Language Teaching. Cambridge: Cambridge University Press.

[10] Seals, Barbara B. \& Richey, Rita C. 1994. Teknologi Pembelajaran: Definisi dan Kawasannya (terj. Dewi S. Prawiradilaga dkk.). Jakarta: Kerjasama IPTPI LPTK UNJ.

[11] Roemiati, Dian. 2005. "Metode Kontekstual dalam Pengajaran Sastra di Sekolah" dalam Konferensi Himpunan Sarjana kesusasteraan Indonesia (HISKI) di Palembang, 18-21 Agustus 2005.

[12] Sugiyono. 2013. Metode Penelitian Kuantitatif dan $R$ \& D. Bandung: Alfabeta.

[13] Sukmadinata, Nana Syaodih. 2010. Metode Penelitian Pendidikan. Bandung: Remaja Rosdakarya.
[14] Sumaryadi. 1987. “Aduh” Karya Putu Wijaya Sebuah Drama Kontemporer dan Hubungannya dengan Pendidikan. Yogyakarta: FKSS IKIP Yogyakarta.

[15] Sutopo, H. B. 2002. Metodologi Penelitian Kualitatif. Surakarta: Sebelas Maret Univercity Press.

[16] Tomlinson,B. \& Masuhara (Eds). 2004. Developing Language Course Materials. Singapore: RELC Portfolio Series.

[17] Waluyo, Herman J. 2003. Drama: Teori dan Pengajarannya. Yogyakarta: Hanindita Graha Widia.

[18] Wiersma, William. 1986. Research Methods in Education: An Introduction. Boston: Allyn and Bacon, Inc.

[19]Zuriah, Nurul. 2007. Pendidikan Moral dan Budi Pekerti dalam Perspektif Perubahan. Jakarta: PT Bumi Aksara. 